\title{
The Role of Professional Library Associations and Institutions in Facilitating Access to Information in Africa
}

\author{
Ngozi Blessing Ossai-Ugbah \\ John Harris Library, \\ University of Benin, Benin City. \\ Edo State, Nigeria. \\ blessing.ossai-ugbah@uniben.edu
}

Doi:10.5901/ajis.2013.v2n2p263

\begin{abstract}
This study is a survey on the role of professional Library associations and institutions in facilitating access to information in Africa. The study traced the history of library association, its stated objectives, the need to join a professional library association, benefits derivable for an association, characteristic of professional library associations and its role in facilitating access to information in Africa. Some of these roles include but not limited to: providing opportunity for librarians to meet, share experiences, learn from each other, develop local library infrastructure and defend the principle of freedom of information. The study however critiqued the professional associations for not being run in professional manners in Africa and lacking cutting technology. It recommended flexibility in running the associations and better funding.
\end{abstract}

Keywords: Professional, Library, Association, Information, Africa.

\section{Introduction}

In today's fast-paced world of business, the need for information is international commodity. Information, both internally and externally produced, is the lifeblood of an organization and essential for innovation and continuous learning. Information sharing is also essential for any organization that is attempting to understand and manage its intellectual capital, often in a global context.

In Africa, people suffer from all kinds of deprivations, ranging from acute food shortage, malnutrition, illiteracy, wars, injustices and human rights denial to dictatorship. Indeed Africa is the most deprived region in the world and thus information is needed in the continent. Unfortunately, the reverse is the case. According to L.O. Aina 1994, information occupies the lowest stratum in the hierarchy of African priorities. Neil (1991) mentioned that the response of the people to library association in Africa has been one of sceptism and apathy and librarians have appeared to have little to offer. Accordingly African governments have lost enthusiasm for library associations and institutions.

\section{Professional Library Associations And Institutions}

Professional Associations and institutions are a great way to gain knowledge of your industry, network and keep on top of current news affecting your industry. Membership in associations also shows your employer and your peers that you are serious about your commitment to your career. Joining an association may be the best investment you make for your career.

Professional associations are found in great abundance and variety from the strictly local to the international. Practitioners of most professions and people of many special interests band together into associations. In psychological terms, such groups are a means by which individual try to distinguish themselves from the masses by aligning with a group that behaves differently and then adhering to the standards of that group. It has been suggested by sociologists and anthropologists that such groups must tolerate some deviation from their standards or risk losing members through an overly strictly insistence on adherence to rules (Herskoyits, 1945). One reason that individuals in our occupation form and join professional association is "to establish identity as a member of the library profession or, given the wide latitude most library associations offer, to indicate ... interest in librarianship and its improvement" (Sullivan, 1976). 
Each professional association and institution also recognize the importance of codifying and making known to the profession and to the general public the ethical principles that guide the work of librarians, other professionals providing information services, library trustees and library staffs. The Code of Conduct indicates the standards of behavior expected of a member of the Association. It sets out, in general terms, the standards and duties which is reasonable, to expect a professional to observe. This can be used as a point of reference when dealing with disciplinary procedures against members. This is intended to protect the profession, individual practitioners, and their clients. This Code of library Professional Conduct was approved by Library Association Council in the Annual General Meeting in 1983, in accordance with The Library Association's Bye-law 45(a). Examples of some of these set guidance and rules are:

- Members of the Association must conduct themselves in such a way that their conduct would not be reasonably regarded by their professional colleagues within the field of librarianship (including the provision of information services) as serious professional misconduct or as professional misconduct. It is by this overall test that the conduct, will be judged.

- Members must not engage in conduct which may seriously prejudice the standing and reputation of the library profession or of their Library Association.

- Members must not divulge or permit to be divulged any materials, information or administrative record (in manual or electronic form) which has been entrusted to them in confidence, to any third party nor use such information without the prior consent of the client for any purpose other than that for which it was first obtained. This duty to the client continues after the relationship of librarian and client ceases.

- Members should not knowingly promote material the prime purpose of which is to encourage discrimination on the grounds of race, color, creed, gender or sexual orientation and etc.

\section{The Need For Professional Library Association And Institution}

There are many numbers of reasons why librarians choose to join associations. "According to a 1992 survey of academic librarians in California, 98 percent of the respondents considered the opportunity to network with colleagues as a very important or somewhat important reason to join professional associations; 81 percent felt that professional membership was important for retention, tenure, or promotion; 84 percent used professional memberships to influence librarians' professional goals and to keep up with developments in the field through professional journals; and 74 percent used their association membership to speak or publish- (Kamm, Sue "To join or not to join: how librarians make membership decision about their associations." 46 (2) Library Trends (Fall 1997): 295-306.)

Associations are seen as relevant sources of information and knowledge sharing and a way to make contacts with others. Information professionals recognize that they need relevant information to be effective in their positions and that practical up-to-date information is readily and openly shared at association conferences and in association publications, listservs and websites. Association committees, interest groups, discussion groups and round tables further provide informal settings for information

The American Library Association is the oldest and largest library association in the world which was established in 1876 in Philadelphia. Presently it has more than 64,000 members. Its mission is "to provide leadership for the development, promotion, and improvement of library and information services and the profession of librarianship in order to enhance learning and ensure access to information for all. Its membership is open to "any person, library, or other organization interested in library service and librarianship...upon payment of the dues provided for in the bylaws."

ALA offers professional services and publications to members and nonmembers, including online news stories from American Libraries and analysis of crucial issues from the Washington Office. There are different types of library associations: the very prominent ones are those where membership is granted on the basis of being in that country, or region, as in these examples: American Library Association (ALA), Library Association of Singapore (LAS), or the Congress of Southeast Asian Librarians (CONSAL). Others may be based on nature of the library collections or the Clientele they serve, as in these examples: Special Libraries Association (SLA), International Association of Technological University Libraries (IATUL) or Association of Research Libraries (ARL). The more unique ones offer membership based on ethnicity or religion. For instance, there are the American Indian Library Association, the [ChineseAmerican Librarians Association, the Asian/Pacific American Librarians Association, the Black Caucus of the American Library Association, the Association of Jewish Libraries, and the Catholic Library Association.

Finally, there are international library associations that are truly global, like the International Federation of Library Associations (IFLA), the Chartered Institute of Library and Information Professionals (CILIP) and large associations that 
are adding international components, like the International Association of Agricultural Information Specialists (IAALD). Other not-so-large international associations offer membership to a specific professional grouping, type of library or a specific subject area. Those professional associations are distinguished by their common issues and trends, including their ability to communicate with their members, their ability to conferences, and their need for self-evaluation. There are also local professional association like the Nigerian library Association (NLA), Nigerian School Library Association (NSLA), and National Library of Nigeria (NLN).

\section{Objectives of Professional Library Association and institutions.}

These objectives are in line with the Tanzania Library Association (TLA) which was established in 1973, after the dissolving of the East African Library Association (EALA). Ever since it has remained the only professional association that safeguards the interests of all library and information personnel in Tanzania. Their main objectives are:

- To unite all persons working in or interested in library work, by convening conferences and meetings for the discussions of matters affecting libraries- their regulations, management or otherwise.

- To encourage the promotion, establishment and improvement of libraries and library services in the United Republic of Tanzania.

- To promote and encourage bibliographical study and research.

- To improve the standard of librarianship and the status of the library profession in the United Republic of Tanzania.

- To watch any legislation affecting libraries find to assist the promotion of such further legislation as may be considered necessary for the regulation and management or extension of library services in the United Republic of Tanzania.

- To collect, collate, and publish (as journals, transactions, bulletins), information of benefit to members of the Association, or for the promotion of the objectives of the Association, AND

- To do all such lawful things as are incidental or conducive to the fulfillment of the above objectives.

In pursuing these objectives, the Association performs the following activities SUCH AS Workshops, Short courses, Film programmes, Short talks, International conferences participation, Publication of Newsletter, Online discussions and collaboration information dissemination are adopted.

\section{Characteristics of professional Library Associations}

Virgo (1991) excellent summary of "professional association" includes characteristics, which are not limited to associations in the library profession:

- Volunteer membership;

- Access to a large number of people in the profession;

- (Members) ....who collectively have a tremendous wealth of experiences in a common field;

- Access to pooled funds to attack problems that are industry-wide.

- General standards for the performance of its members and the expectation of continuing professional development;

- Literature for dissemination research developments and reports

- The ability to attract a significant mass of the profession to meetings;

- The numbers to speak on behalf of the profession on issues affecting the profession; and

- The perception by outside group as an ability about matters relating to that profession.

\section{Activities and Services of Professional Library Associations.}

These activities are in line with the International Federation of Library Associations and Institutions (IFLA), which is a worldwide, independent, nongovernmental organization. The purposes of the Federation as stated in its Statutes are "to promote high standards of delivery of library and information services; to encourage widespread understanding of the value and importance of high quality library and information services in the private, public and voluntary sectors; and to represent the interests of its Members throughout the world." These activities are to be incorporated into the professional 
programmes throughout IFLA's organizational structure, recognizing especially that the needs, concerns and views of every region of the world are to be taken into account, particularly those in the developing world. Regional concerns, communication and information exchange among IFLA's members and the use of electronic technology to facilitate the implementation of its priorities underpin all of these professional priorities.

\section{Functions Of Professional Library Associations}

Rice (1992), states that there's practically a professional association for every industry you can think of, and these 'peak bodies' perform a variety of functions such as:

- establishing and monitoring industry standards and professional codes of practice

- advising educational institutions on curriculum development

- promoting and providing professional and career development activities

- providing a forum for member networking

- $\quad$ promoting the profession in the community

- providing career information to prospective students

- assisting graduates with career planning and job seeking

- maintaining a professional library for members, and

- Producing regular publications on professional and industry issues eg. newsletters or magazine/journals.

Professional associations and institutions also can:

- increase your knowledge of the profession and industry you are interested in, which will help you to decide whether you wish to pursue a career in this field,

- increase your knowledge of companies and organisations and the career opportunities they offer,

- learn about day-to-day issues you will face in the workplace

- remain up-to-date with developments in the field

- network with prospective colleagues and employers socialize with fellow students who share similar interests and career goals

- develop skills through participation in professional development activities

- learn about and apply for vacation work, co op placements and other work experience opportunities

- Receive assistance with job seeking through workshops, seminars, site visits, employer functions, vacancy listings etc.

- work for the association on projects and develop new skills, and

- improve your business etiquette and communication skills

\section{Role of Professional Associations and Institutions in facilitating access to information in Africa.}

Library professional associations provide career opportunity for librarians, to meet and share experiences and learn from each other. They offer a range of services to members and look after their interests. For outsiders interested in dealing with the profession, they act as the ideal contact point. Although library associations do serve the needs of their members, ultimately, the long term benefactors are the end-users of the services that these members provide. They lay down standards for performance, protect the continuing existence of special services and monitor the trends in user needs (Sullivan, 1997, p. 135).

Information professionals play a unique role in gathering, organizing, and coordinating access to the best available information sources for the organization, understanding the critical need of turning that information into usable knowledge.

This is accomplished through the development, deployment, and management of information resources and services. Information professionals, working in non-traditional settings such as market research, business development, and strategic planning, use the Internet and other technology to present information in a way that maximizes its usefulness, saving time and money in order to attain the goals of their organization. Organizations that are integrating information professionals into strategic planning initiatives recognize their necessity in gaining a competitive advantage in the information and knowledge age. However, the following are some of the roles that are performed by IFLA-African section (IFLA Africa Section Committee held in Gaborone, Botstvana in February 2004): 
Supporting the Infrastructure of Library Associations locally. IFLA supports the infrastructure of library associations, especially in countries and regions where these are poorly developed, because they provide the essential means for accomplishing IFLA's goals at the national level.

Developing Library Professionals - For instance IFLA works in strengthen the abilities and knowledge of library and information science professionals find paraprofessionals throughout the world in order to improve service to the user. Programmes supported by IFLA encompass all educational processes, including library and information science curricula and continuing education activities such as lectures, seminars, workshops and in service training.

Providing Unrestricted Access to Information - IFLA seeks to influence political and economic decisions that have an ethical impact on access to information so that all persons throughout the world have the same opportunity to participate in the information society without regard to physical, regional, social, or cultural barriers. Ongoing technological progress seems to widen the gap between the information rich and the information poor world-wide. IFLA supports programmes which provide support for information access in developing regions of the world.

Defending the Principle of Freedom of Information - IFLA believes that all people have a fundamental right to create and acquire information and to express their views publicly. The right to know and the freedom to express are two aspects of the same principle. Libraries play a key role in securing these rights, and IFLA supports this role by defending the ability of libraries to acquire, organize, preserve and make available the widest variety of materials, reflecting plurality and diversity in the society, and thus to protect and enhance democracy and a free debate; by defending the ability of libraries to ensure that selection and availability of material and services are governed by professional principles, not the political, moral or religious views of individuals or governments; and by defending the ability of libraries to make materials and services available to all users, with no discrimination due to race, creed, gender, religion, age or any other subjective reason.

Promoting Resource Sharing - IFLA serves as an international forum and advocate for sharing information in all its forms across national borders. It promotes the communication of bibliographic information which is the basis for all resource sharing.

Supporting the Role of Libraries in Society - IFLA supports the establishment and maintenance of libraries by serving as an international advocate to ensure that the vital role of libraries in the digital age is well understood and acted upon. IFLA lobbies on behalf of libraries with government officials and community leaders, using all available avenues to secure appropriate funding and staffing of library services worldwide.

\section{Benefits of Professional Library Association and Institutions in Africa.}

Library professional encourage lifelong learning through training courses on a regular scheduled basis for their members. (Enser,2001). They offer annual training conferences that allow members to work cooperatively with each other, to learn research results, and to apply them in their respective professional settings. These are usually supplemented by local or regional conferences that offer informal opportunities for practitioners in the same geographic area or functional specialty to "network" with each other.

Professional association often offers other services to individual organizational members. These may include publications, technical assistance, newsletters, legal updates, and other information of interest to practitioners.

Of increasing importance in the internet era is their ability to make information, publications and internal communications available to members through their listservs and internet sites. These are particularly of interest to international members because they eliminate the needs for postage, and increase free access to teaching and learning materials which would otherwise be beyond the reach of many international members, or impractical to access. This includes electronic journals and newsletters.

In the context of supporting strategies leading to the continued revitalization and renewal of African university libraries, International Network for the Availability of Scientific Publications INASP, has established a programme to:

- Strengthen the role of regional professional associations in assisting and promoting the development of African university libraries;

- Encourage networking and information exchange between all university libraries in Africa.

\section{Challenges Of Professional Library Association And Institutions In Africa}

Using technology well, particularly email, Internet access, video conference and faxing, is both a challenge and a saviour 
for many associations. Members especially expect that information will be forwarded to them electronically and updated regularly. As we all struggle with reviewing our publications programs and relaunching our websites, we must be cognizant of that fact that our diverse groups of members have different needs and wants. Simply transferring print publications to websites won't work and are not desired by everyone, and a gradual transition may be required. (Jingli, 2001)

Also the cost of implementing new technology delivery channels is also expensive. Actual costs and the hidden costs in terms of staff time, the challenges in changing how we think about and deliver information to our members, and continually evaluating the effect. While working for us, technology can also work against us, since many in the profession perceive that the networking aspect of associations has been made less important by electronic networking. The road to change and ongoing advancement won't be easy. Organizations like ours, which rely heavily on volunteers, necessarily take longer to make decisions and direct change. Our boards and committees meet only a few times a year. The strategic planning process can take years and implementation even longer. The key will be to project ourselves far enough in the future in order to keep up with what is happening around us and to be ahead of the game.

Also we lack recognition especially in African, and I think it is because we don't always recognize it ourselves. Mostly because we don't communicate what we do well and we don't promote ourselves the way we should. As a profession we have shied away from paper qualifications, which could go a long way to establishing a standard for the members of the profession and helping the public to understand what our profession does and stands for. We have also done a rather poor job of marketing ourselves and have fragmented into so many groups and associations that no one group has the resources or support to establish a clear definition of what it is we do and could do as a profession. New graduates are coming out with a radically different set of skills than those who have been out a few years ago did. It is up to us to entice the best students we can into the profession. Students are looking for careers that are exciting, interactive and challenging. Our profession can be all of that, but we are seldom given a second glance. Often we are the employers of librarians and it is up to do our best to change how we reward our staff. Lack of Partnerships between libraries, between library associations, and between the library profession and other professions is also a key role.

\section{Critique Of Professional Library Associations And Institutions In Africa}

Professionals are not prepared to articulate the current issues at any given time. High-profile issues in today's library field are filtering, outsourcing/privatization, free vs. fee-based services, intellectual freedom and the broadening gap between technological haves and have-nots.

Professionals should communicate and often defend the tenets of their profession but Library Professionals associations in Africa do not communicate and defend the tenets of their profession as well as the needs of their communities. They are not skilled at communicating to both individuals and groups.

Professionals must learn to make responsible choices for the future but we find out that Library professionals associations in Africa do not learn to make responsible choices for the future about the issues that will face library professionals in the future which include Access vs. ownership of materials; dwindling funding for print-based materials; space and facilities use for computers; and ongoing technology training for staff.

Membership and activity in professional associations in Africa do not enrich professional life; it should be an association which is an impressive organization that provides support, publications and training opportunities. Participation in professional organizations should also be able to improve your work, as well as broaden your employment possibilities and also revitalize professional's attitude towards member's profession.

Although levels of success can be defined differently, neither salary nor sixes of library are indicators of success in the library profession. Standards of excellence benchmarked against others are what should be the ultimate measures for library professionals. Library professional associations use the satisfaction of members to measure excellence but in Africa the satisfaction of the members is the least in measuring of success achieved by the association.

Leaders in professions provide leadership by leading the profession as a group through association or community work, role modeling, mentoring, research and publishing. The leadership roles of mentoring and role modeling provide professionals one-on-one attention that helps them to be successful in their communities and in their profession. They lead by action, writing and researching, The saying "following the actions and writings of leaders is an excellent path to becoming a stronger leader" but this is not applicable in Africa because they leaders do not lead by action, writing and researching, but by politics. 
Dining the third meeting of the United Nations Economic Commission for Africa (UNECA)'s Committee on Development Information (CODI) held from 12 to 17. May 2003, in Addis Ababa, attended by librarians from Botswana, Ethiopia, Djibouti, Egypt, Ghana, Tanzania, Zambia and Nigeria, it as observed that advocacy for libraries and information services on the continent was lacking. It was noted that there are several activities and programmes being implemented on the continent and around the world to which librarians in Africa could provide inputs and influence decisions for the good of libraries and information services on the continent. However, the library professionals are not doing much. Among the activities or programmes that were identified are the following:

- African Information Society Initiative (AISI)

- New Partnership for African Development (NEPAD)

- African Renaissance

- World Summit on the Information Society (WSIS)

- African Networks Campaign on Education for All (ANCEFA)

- Dakar Framework for Action

- Global Campaign for Education.

It was further noted that even if librarians on the continent were to decide to provide inputs into the above programmes/activities, it would be difficult to speak with one voice since they do not have a forum through which advocacy activities could be conducted.

Also Associations do not make it easy for members to get involved in activities. Many of our associations are quite complex and members are unsure of how they can become involved. Committee membership can realistically be open to only a small percentage of members and serving on an executive board requires a fair amount of time as well as a certain level of knowledge about the running the association generally gained through working with the association over time

Also the professional library association and institution in African are not generally doing much in facilitating access to information in Africa like their counterparts in the developed countries, this as a result of inconsistency in their publication, lack of ICT facilities to aid their publication and disseminate information and also disunity amongst them which have made them not to have a forum that generally meets the needs of their continent like IFLA.

Finally, we simply cannot expect that, our associations will have relevance simply because they exist. It is only through careful planning which takes into account the needs of the members and the non-members (the public and the community, the available resources, future changes to the profession, and the external environment that library associations will continue to be relevant and strong in the future.

\section{Findings}

A. African professional library association and institutions have the challenge to efficiently and effectively manage information in the 21st century in order to facilitate technology transfer, support teaching, learning and research, and project Africa's achievements and potentials to the rest of the world for mutual benefits.

B. The librarianship profession in Africa has been lacking in the knowledge of the right steps to take in facilitating access of information for development

\section{Recommendation}

A. Associations must be flexible and open to change. A number of international associations are undergoing a complete and thorough review of their structures and operations in an attempt to manage their future activities and the ones in African countries are expected to do so.

B. Professional library associations should be steered by principles of: clear vision of the future; non-parochial policies; bringing on board other stakeholders in an information society; and building on international partnerships.

C. When charting the course of library associations in the evolving information society, the structure and management of library associations, member expectations, user sophistication and professional ethics have to be taken into account.

D. The problem of lack of advocacy for libraries and information services at the highest level in Africa should be addressed as soon as possible. This could be clone by forming a library and information services advocacy forum by librarians on the continent. 


\section{Conclusion}

Professional library association and institutions in facilitating access to information in any nation can be both indigenous and international. For African countries to harness information from local sources and overseas, the application of modern information management techniques is a sine qua non. Africa has much to offer to the world just as the world has much to offer to Africa (see 68th IFLA council and general conference proceedings, August, 2002). One therefore expects these professional associations and institutions to do more in developing information access, especially in schools, libraries and communities in Africa in the 21st Century. However, as development issues, especially science and technology there is need for African countries to access and utilize information for development, no matter the format, no matter the source. The challenge to do this is much for professional library associations, institutions in Africa and their sponsors indeed (Library and information commission, 2000).

\section{References}

Alemna, A. A. Library Associations in Africa and the case for professionalism. Library Review. 44 (1).

American Association of Law Libraries. Core Competencies of Law Librarianship. http://www.aallnet.org/prodev/ competencies.asp.

Berghahl, B. (1989). IFLA's Programme Advancement of Librarianship in the Third World ALP: A proposal for the Future, Stockholm: Swedish Library Association. P. 41.

Enser, P. (2001). On continuity, culture, competition-cooperation and convergence, too. New Library World. 102: 423-428.

Gupta, S. (1993) Development of the Library Profession and Education in Ethiopia. International Information and Library Review. 25: 7383.

Hull, B. (2001). Can librarians help to overcome the social barriers to access? New Library World. 102(10): 382-388.

Kigongo-Bukenya, (2003). Establishment of Library and Information Schools Network in the Eastern, Central and southern Africa Region (LISNET-ECS) Project proposal to be funded by IFLA-ALP as a Pre-conference Workshop preceding the Standing Conference of Eastern, Central and Southern Librarians (SCECSAL XVI) 6th - 9th July 2004, Kampala, Uganda.

Neill, J. R. The Marginalized workforce: Africa's Library and Information Profession. (1991). African's Journal of Library, Archives and Information Sciences. 1: 9-18.

Ocholla, D. N. (1992) Developing an Infrastructure for Scientific Information in Kenya. Library Review. 41 (5): 48-59.

Oehlschlaeger, S. (2000). "From Confusion to Fusion: the Fusion of Librarians' Associations in Germany". RTMLA Newsletter. 23: 1215.http://www.ifla.org/VII/rt6/ news/vol2 .pdf

Olabede W. A. (1999). Education for Information Science in Africa. The ARCIS Perspective. In: Project Report No. 14 - Education for Librarianship and Information Science in Africa. Edited by Wise, M. Pp. 251-263

Parent, R.H. (1995) "Strategic Planning for Library Associations". IFLA Journal 14 (4): 343-353.

"Professional" is Only a Label'. (1998). Library Journal. 1: 6.

Qwelane, I. M. (2002 Advocacy for Democracy: the Role of Library Associations". 66th IFLA RTMLA Open Session, Jerusalem, Israel, August 15. http://www. ifla.org/ IV/ ifla66/ papers/064-1222.htm

Raseroka, K. (2002). "How Do We Wake Awareness about Ourselves: Advocacy and Policy Development in Library Associations". 63th IFLA Conference, Copenhagen, Denmark, August 1997. http://www.ifla.org//V/ifla63/63rask.htm.

Riggs, D. E. (1998). "The Growing Importance of State Library Associations". College \& Research Libraries. 59(6): 500-501

Roa, D and A. Neelameghan. "The School of Information Science in Africa (SISA)" Libra. 42 (3): 242-257

Steendam, E. (2002). The 21st Century Information Society: the Role of Library Associations. European Commission on Preservation and Access. http://www.knaw.nl/ecpa/ conference/ Buda2.html

Storms, M. (1998). "Can One Association Wear Two Hats: Membership.. Versus Advocacy?" 64th IFLA Conference, Amsterdam, the Netherlands, August. http://www.ifla.org/IV/ifla64/09097e.htm

Williams, H.P. (1981). "Professional education: a personal view. International Library Review. October 13 (4): 335. 